\title{
Effect of Wax Coating on the Quality of Cucumber Fruits during Storage
}

Adel H Bahnasawy* and El-Sayed G Khater*

Agricultural Engineering Department, Faculty of Agriculture, Benha University 13736, Egypt

\begin{abstract}
The main objective of this work was to study the effect of waxing (control, 25, 50, 75 and 100\%) and storage temperature (room temperature, 15,10 and $5^{\circ} \mathrm{C}$ ) on cucumber fruits quality. The diameter change, length change, volume change, surface area change, weight loss, hardness change rate, Total Soluble Solids (TSS) were studied as the most important factors affecting the fruit quality. Shelf life of cucumber fruits was also determined. The obtained results indicated that the diameter change decreases with increasing wax solution, meanwhile, the diameter change increases with increasing storage temperature. The length change decreases with increasing wax solution and it increases with increasing storage temperature. The volume change decreases with increasing wax solution, meanwhile, it increases with increasing storage temperature. The surface area change decreases with increasing wax solution but it increases with increasing temperature storage. The weight loss decreases with increasing wax solution but it increases with increasing storage temperature. The hardness change rate decreases with increasing wax solution but it increases with increasing storage temperature. The TSS decreases with increasing wax solution but it increases with increasing storage temperature. The shelf life increases with increasing wax solution but it increases with increasing storage temperature.
\end{abstract}

Keywords: Wax coating; Storage temperature; Cucumber; Fruit size change; Weight loss; TSS; Hardness; Shelf life

$\begin{array}{cl}\text { Nomenclature } & \\ \text { - DC } & \text { diameter change }(\mathrm{mm}) \\ \text { - WC } & \text { wax coating }(\%) \\ \text { - } \mathrm{T} & \text { temperature }\left({ }^{\circ} \mathrm{C}\right) \\ \text { - } \mathrm{LC} & \text { length change }(\mathrm{cm}) \\ \text { - } \mathrm{WL} & \text { weight loss }(\%) \\ \text { - } \mathrm{VC} & \text { volume change }\left(\mathrm{cm}^{3}\right) \\ \text { - } \mathrm{SAC} & \text { surface area change }\left(\mathrm{cm}^{2}\right) \\ \text { - } \mathrm{H} & \text { hardness }(\mathrm{kg}) \\ \text { - } \mathrm{TSS} & \text { TSS change }(\%) \\ \text { - } \mathrm{SL} & \text { shelf life (hour) }\end{array}$

\section{Introduction}

Cucumber (Cucumis sativus L.) is an important vegetable belonging to the family of Cucurbitaceae. Cucumbers contain approximately $95 \%$ water, $3.6 \%$ carbohydrates, and $0.65 \%$ protein, and are low in calories $\left(150 \mathrm{kcal} \mathrm{kg}^{-1}\right)$. They are a good source of the following nutrients (in $\mathrm{mg}$ $\mathrm{kg}^{-1}$ ): pantothenic acid (B5) (0.026); vitamin C (0.28); magnesium (1.3). Cucumbers are grown both as a source of pickles, and to be eaten fresh. While consumption of pickles has been waning, the use of cucumbers as a fresh vegetable has been increasing [1]. Cucumber (Cucumis sativus $L$.) is a favorite commodity exports for markets and local consumption and represents one of the most important and economic vegetables in Egypt. It is grown in Egypt in the open field from March to November and under plastic houses from September to May. The total cultivated area of cucumber in Egypt was about 27989 ha in 2011 according to the statistics of CAPMS [2]. Waxing was used as a preservation technique for fruits since 1900. Wax has been used since pre-historic times. In $4200 \mathrm{BC}$, the ancient Egyptians kept bees and used the wax from honeycombs to make models and to preserve their dead and in encaustic painting. The Chinese were using waxing processes on fruits, but it was not until 1922. Waxes are used to replace some of the natural waxes that removed in washing and cleaning operations, and this helps to reduce the water loss during handling and marketing. If produce is waxed, the wax coating is allowed to dry thoroughly before further handling. Waxing of the produce is an old age art, which was started in the beginning of the $19^{\text {th }}$ century [3].

Water loss can be controlled by altering the fruit surface or by proper control of storage conditions. Examples of the first method are the application of artificial wax coatings and heat treatments. Artificial, edible coatings are generally applied by spraying or dipping after removal of the natural wax. The effectiveness of the coating depends on the thickness, concentration, and type of coating $[4,5]$.

To avoid deterioration, cucumbers are often stored and transported at cold temperatures. However, cucumbers are among a number of tropical and subtropical crops that are sensitive to above-freezing cool temperatures. Low-temperature storage of cucumbers may induce damage associated with Chilling Injury (CI), resulting in compositional as well as in morphological (structural) and microbiological changes [6-14].

The susceptibility of cucumbers to chilling injury and to yellowing restricts desirable storage temperatures to a narrow range. If held at $10^{\circ} \mathrm{C}$ or colder, they suffer from chilling injury; if held at $15^{\circ} \mathrm{C}$ or higher, they rapidly become yellow. Thus, the optimum temperature is 12 to 13 . However, for storage of 1 to 2 weeks, $10^{\circ} \mathrm{C}$ is preferable because chilling is minimal and yellowing is retarded, although [15] claims that yellowing is slower at $13^{\circ} \mathrm{C}$ than at higher or lower temperatures. The same author found that differences in chilling sensitivity among cultivars are minor.

*Corresponding authors: Adel H Bahnasawy, Agricultural Engineering Department, Faculty of Agriculture, Benha University 13736, Egypt, Tel: +20132467034; E-mail: adel.bahnasawy@ fagr.bu.edu.eg

El-Sayed G Khater, Agricultural Engineering Department, Faculty of Agriculture, Benha University 13736, Egypt, Tel: +20132467786; E-mail: alsayed.khater@fagr.bu.edu.eg

Received March 24, 2014; Accepted June 20, 2014; Published July 03, 2014

Citation: Bahnasawy AH, Khater EG (2014) Effect of Wax Coating on the Quality of Cucumber Fruits during Storage. J Food Process Technol 5: 339. doi:10.4172/2157-7110.1000339

Copyright: @ 2014 Bahnasawy AH, et al. This is an open-access article distributed under the terms of the Creative Commons Attribution License, which permits unrestricted use, distribution, and reproduction in any medium, provided the original author and source are credited. 


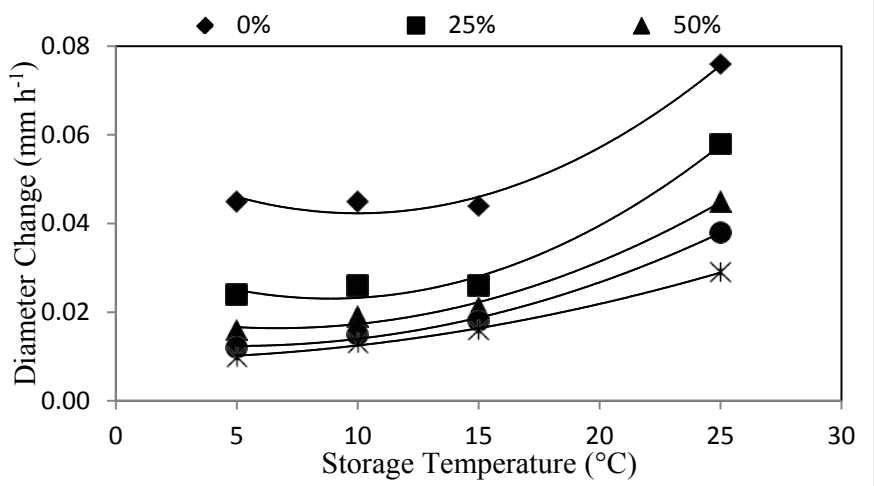

Figure 1: Effect of wax solution concentrations on cucumber fruit diameter change at different storage temperatures.

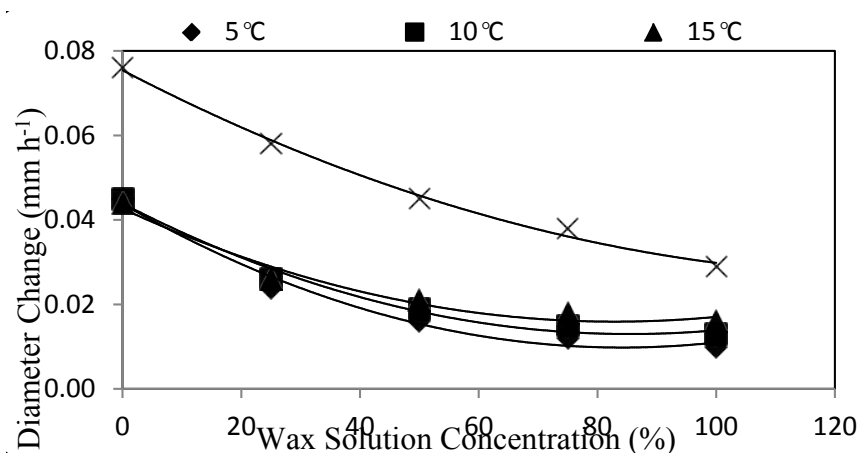

Figure 2: Effect of storage temperature on cucumber fruit diameter change at different wax solution concentrations.

The susceptibility of cucumbers to chilling injury does not preclude their exposure to temperatures below $5^{\circ} \mathrm{C}$ as long as they are utilized immediately after removal from cold storage, because symptoms develop rapidly only at higher temperatures. Thus, 2 days at $0^{\circ} \mathrm{C}, 4$ days at $5^{\circ} \mathrm{C}$, or 8 days at $7^{\circ} \mathrm{C}$ are harmless under these conditions [16]. They added that cucumbers can be expected to remain in good condition for 10 to 14 days at $10^{\circ} \mathrm{C}$. For fruits harvested relatively young, where yellowing is not an immediate problem, $13^{\circ} \mathrm{C}$ would be preferable and may extend the storage life 2 to 3 days and proper Controlled Atmosphere (CA) conditions may add a further 4 to 6 days, for a total of about 3 weeks.

Cucumber fruits are losing too much moisture, exposed to damage and bruising, losing the good appearance during handling and storage process, so that using wax as coating is the most common practice to prevent moisture loss, protect the fruits from damage and bruising, increase the shelf life and improve the fruit appearance, which in turn increase the marketability of the cucumber. To prolong storage quality and postharvest shelf life, the cucumber was waxed with different solution concentrations and stored at different temperatures. The appearance indices weight loss and cucumber shelf life were determined as the most important factors affecting the final quality of cucumber during storage.

\section{Materials and Methods}

The experiment was carried out at Agricultural Engineering
Department, Faculty of Agriculture, Moshtohor, Benha University, during the period of June to July, 2012.

\section{Materials}

The Cucumber (Cucumis sativus L.) was brought from the Faculty of Agriculture Farm, Moshtohor, Benha University after harvesting.

Paraffin wax is mostly found as a white, odorless, tasteless, waxy solid, with a typical melting point between about 46 and $68^{\circ} \mathrm{C}(115$ and $154^{\circ} \mathrm{F}$ ), and having a density of around $0.9 \mathrm{~g} / \mathrm{cm}^{3}$. It is insoluble in water, but soluble in ether, benzene, and certain esters. Paraffin is unaffected by most common chemical reagents but burns readily.

Refrigeration room used in this study has a dimension of $3.0 \mathrm{~m}$ length, $3.0 \mathrm{~m}$ in width and $3.0 \mathrm{~m}$ height. It made prefabricated insulated panels of thickness of $60 \mathrm{~mm}$. the panels insulation are covered with precoated stainless steel sheet on both sides.

\section{Methods}

The cucumber fruits were dipped into a $0,25,50,75,100 \%$ wax solutions. The fruits were then fan-dried at room temperature (approximately $25^{\circ} \mathrm{C}$ ). The waxed fruits were stored at four temperature $5,10,15^{\circ} \mathrm{C}$ and room temperature $\left(25^{\circ} \mathrm{C}\right)$. Twenty treatments were applied (five wax solution concentrations and four storage temperatures) and replicated 3 times.

\section{Measurements}

The dimensions of fruits (length and diameter) were measured by digital vernier caliper (Model TESA 1p65- Range 0-150 mm \pm 0.01 $\mathrm{mm}$, Swiss). The mass was measured by electric digital balance (Model HG - 5000- Range 0-5000 g $\pm 0.01 \mathrm{~g}$, Japan). The surface area was measured by wrapping aluminum foil around the cucumber fruit and then cutting the foil away with scissors into thin strips sufficient to lay the foil flat. A planimeter (Model Placom KP -90 N- Range 0-10 $\mathrm{m}^{2} \pm$ $0.2 \%$, Japan) was used to measure the surface area of the cucumber. The volume of fruits was measured by graduated cylinder. The hardness was measured by Hardness meter (Model GY-1-Range 2-15 kg cm${ }^{-2} \pm 0.1$ $\mathrm{kg} \mathrm{cm}^{-2}$, China). The TSS was measured by Refractometer (Model HR010-Range 0-10\% Brix $\pm 0.1 \%$ Brix, Japan). These measurements were repeated three times and the average was taken before and after storage.

\section{Results and Discussion}

Cucumber quality was determined by measuring the change of fruit diameter, length, volume, volume, surface area, mass, hardness and total soluble solids (TSS). Weight loss and shelf life of the fruit during storage were also studied.

\section{Effect of wax coating and storage temperature on the fruit size change}

Diameter change: Figures 1 and 2 show the effect of different wax solution concentrations and storage temperatures on change in cucumber fruit diameter. The results indicated that the change of diameter decreases with increasing wax solution concentrations, meanwhile, the diameter change increases with increasing storage temperature, where, it decreased from 0.053 to $0.017 \mathrm{~mm} \mathrm{~h}^{-1}$ when the wax solution increased from 0 (control) to $100 \%$. On the other hand, loss of diameter increased from 0.021 to $0.049 \mathrm{~mm} \mathrm{~h}^{-1}$ with the storage temperature increased from $5^{\circ} \mathrm{C}$ to $25^{\circ} \mathrm{C}$ (room temperature). These results agreed with those obtained by [16]. The overall average of diameter change decreased from $0.053 \pm 0.014$ to $0.017 \pm 0.007 \mathrm{~mm}$ $\mathrm{h}^{-1}$ when the wax concentration changed from 0 to $100 \%$. The overall 
Citation: Bahnasawy AH, Khater EG (2014) Effect of Wax Coating on the Quality of Cucumber Fruits during Storage. J Food Process Technol 5: 339. doi:10.4172/2157-7110.1000339

Page 3 of 8

\begin{tabular}{|c|c|c|c|c|}
\hline \multicolumn{5}{|c|}{ Cucumber Diameter Change } \\
\hline \multirow{2}{*}{$\begin{array}{c}\text { Wax Solution Concentrations } \\
(\%)\end{array}$} & \multicolumn{3}{|c|}{ Constants } & \multirow{2}{*}{$\mathbf{R}^{2}$} \\
\hline & A & b & c & \\
\hline 0 (control) & 0.0001 & -0.0028 & 0.0567 & 0.983 \\
\hline 25 & 0.0001 & -0.0024 & 0.0335 & 0.985 \\
\hline 50 & $6 \times 10^{-5}$ & -0.001 & 0.0129 & 0.994 \\
\hline 75 & $6 \times 10^{-5}$ & -0.0005 & 0.0129 & 0.999 \\
\hline 100 & $4 \times 10^{-5}$ & -0.0001 & 0.01 & 0.999 \\
\hline \multirow{2}{*}{ Temperature $\left({ }^{\circ} \mathrm{C}\right)$} & \multicolumn{3}{|c|}{ Constants } & $D^{2}$ \\
\hline & A & b & c & $\mathrm{R}^{2}$ \\
\hline 5 & $5 \times 10^{-6}$ & -0.0008 & 0.044 & 0.986 \\
\hline 10 & $4 \times 10^{-6}$ & -0.0007 & 0.0442 & 0.983 \\
\hline 15 & $4 \times 10^{-6}$ & -0.0006 & 0.0429 & 0.962 \\
\hline 25 (Room Temperature) & $3 \times 10^{-6}$ & -0.0007 & 0.0751 & 0.997 \\
\hline
\end{tabular}

Table 1: The constants $a, b, c$ and coefficient of determination for diameter change at the different wax solution concentrations and the different storage temperatures.

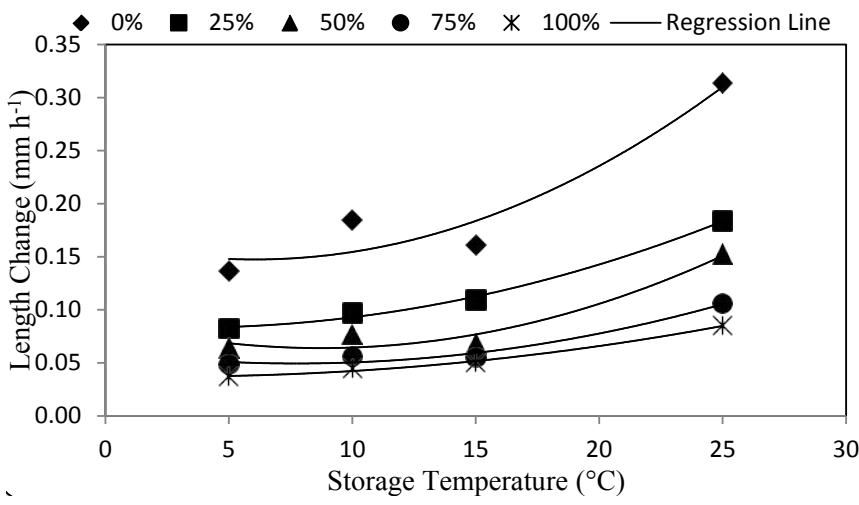

Figure 3: Effect of wax coating on cucumber fruit length change at differen storage temperatures.

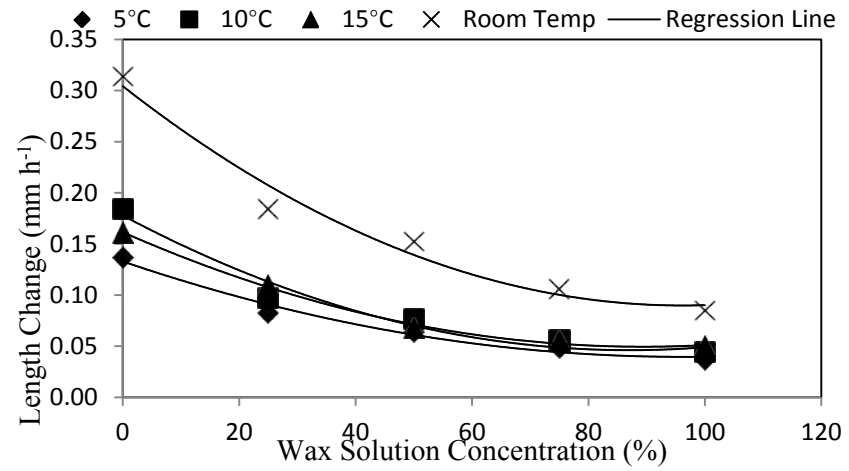

Figure 4: Effect of storage temperature on the cucumber fruit length change at different wax solution concentrations.

average of diameter change ranged from $0.021 \pm 0.013$ to $0.049 \pm 0.016$ $\mathrm{mm} \mathrm{h}^{-1}$ depending on the storage temperature $\left(5\right.$ to $\left.25^{\circ} \mathrm{C}\right)$.

Regression analysis was carried out to find a relation between the fruit diameter change and both wax solution concentrations and storage temperatures. Equation (1) shows the most appropriate form for the relationship between the fruit diameter change and wax solution concentrations at different storage temperatures. Equation (2) shows the relationship between the fruit diameter change and storage

temperatures at different wax solution concentrations. The constants of these equations and coefficient of determination are listed in Table 1.

$$
\begin{aligned}
& \mathrm{DC}=\mathrm{a} \mathrm{WX}^{2}+\mathrm{bWX}+\mathrm{c} \\
& \mathrm{DC}=\mathrm{a} \mathrm{T}^{2}+\mathrm{b} \mathrm{T}+\mathrm{c}
\end{aligned}
$$

Where:-

$\mathrm{DC}$ is the cucumber diameter change $\left(\mathrm{mm} \mathrm{h}^{-1}\right)$

WX is the wax coating (\%)

$\mathrm{T}$ is the storage temperature $\left({ }^{\circ} \mathrm{C}\right)$

Length change: Figures 3 and 4 show the effect of different wax solution concentrations and storage temperatures on change in cucumber fruit length. The results indicate that the length decreases with increasing wax solution and it increases with increasing storage temperature, where, it decreased from 0.199 to $0.0054 \mathrm{~mm} \mathrm{~h}^{-1}$ when the wax solution concentrations increased from 0 (control) to $100 \%$. On the other hand, the length change increased from 0.074 to 0.168 $\mathrm{mm} \mathrm{h}^{-1}$ with the storage temperature changed from 5 to $25^{\circ} \mathrm{C}$ (room temperature). The overall average of length change decreased from $0.199 \pm 0.068$ to $0.0547 \pm 0.018 \mathrm{~mm} \mathrm{~h}^{-1}$ when the wax concentration changed from 0 to $100 \%$. The overall average of length change ranged from $0.074 \pm 0.035$ to $0.168 \pm 0.081 \mathrm{~mm} \mathrm{~h}^{-1}$ depending on the storage temperature $\left(5\right.$ to $\left.25^{\circ} \mathrm{C}\right)$.

Regression analysis was carried out to find a relation between the fruit length change and both wax solution concentrations and storage temperatures. Equation (3) shows the most appropriate form for the relationship between the fruit length change and wax solution concentrations at different storage temperatures. Equation (4) shows the relationship between the fruit length change and storage temperatures at different wax solution concentrations. The constants of these equations and coefficient of determination are listed in Table 2.

$$
\begin{aligned}
& \mathrm{LC}=\mathrm{a} \mathrm{WX}^{2}+\mathrm{b} \mathrm{WX}+\mathrm{c} \\
& \mathrm{LC}=\mathrm{a} \mathrm{T}^{2}+\mathrm{b} \mathrm{T}+\mathrm{c}
\end{aligned}
$$

Where:-

LC is the cucumber length change $\left(\mathrm{mm} \mathrm{h}^{-1}\right)$

Volume change: Figures 5 and 6 show the effect of different wax solution concentrations and different storage temperatures on change

\begin{tabular}{|c|c|c|c|c|}
\hline \multicolumn{5}{|c|}{ Cucumber Length Change } \\
\hline \multirow{2}{*}{ Wax Solution Concentrations (\%) } & \multicolumn{3}{|c|}{ Constants } & \multirow{2}{*}{$\mathrm{R}^{2}$} \\
\hline & a & b & c & \\
\hline 0 (Control) & 0.0005 & -0.0055 & 0.1639 & 0.917 \\
\hline 25 & 0.0002 & -0.0013 & 0.0853 & 0.996 \\
\hline 50 & 0.0003 & -0.0058 & 0.0891 & 0.996 \\
\hline 75 & 0.0002 & -0.0029 & 0.0606 & 0.976 \\
\hline \multirow[b]{3}{*}{ Temperature $\left({ }^{\circ} \mathrm{C}\right)$} & $1 \times 10^{-4}$ & -0.0005 & 0.0378 & 0.995 \\
\hline & \multicolumn{3}{|c|}{ Constants } & \\
\hline & $\mathbf{a}$ & b & c & $\mathrm{R}^{2}$ \\
\hline 5 & $1 \times 10^{-5}$ & -0.0192 & 0.1329 & 0.980 \\
\hline 10 & $2 \times 10^{-5}$ & -0.003 & 0.1778 & 0.971 \\
\hline 15 & $1 \times 10^{-5}$ & -0.0025 & 0.1615 & 0.989 \\
\hline 25 (Room Temperature) & $2 \times 10^{-5}$ & -0.0045 & 0.3043 & 0.973 \\
\hline
\end{tabular}
in cucumber fruit volume. The results indicated that the volume change decreases with increasing wax solution concentrations, meanwhile, it increases with increasing storage temperature, where, it decreased from

Table 2: The constants $a, b, c$ and coefficient of determination for length change at the different wax solution concentrations and the different storage temperatures. 


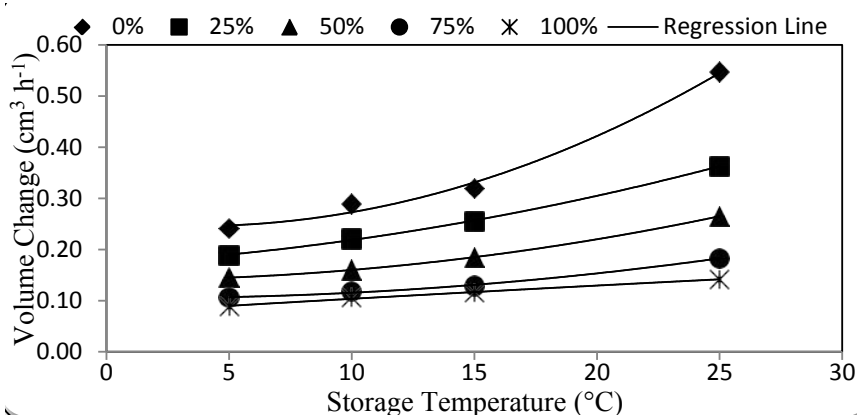

Figure 5: Effect of wax coating on cucumber fruit volume change at different storage temperatures.

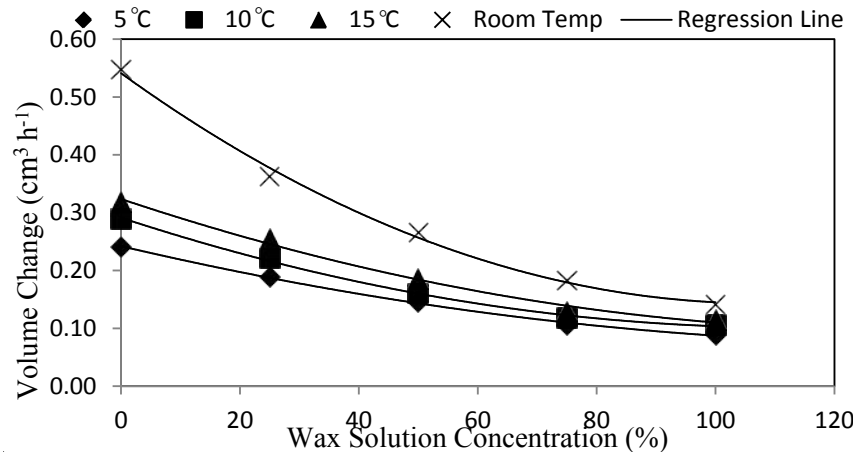

Figure 6: Effect of storage temperature on the cucumber fruit volume change at different wax solution concentrations.

0.349 to $0.113 \mathrm{~cm}^{3} \mathrm{~h}^{-1}$ when the wax solution increased from 0 (control) to $100 \%$. On the other hand, loss of volume cucumber fruit increased from 0.154 to $0.300 \mathrm{~cm}^{3} \mathrm{~h}^{-1}$ with the storage temperatures increased from 5 to $25^{\circ} \mathrm{C}$ (room temperature). The overall average of volume change decreased from $0.349 \pm 0.118$ to $0.113 \pm 0.019 \mathrm{~cm}^{3} \mathrm{~h}^{-1}$ when the wax concentration changed from 0 to $100 \%$. The overall average of volume change ranged from $0.154 \pm 0.056$ to $0.300 \pm 0.145 \mathrm{~cm}^{3} \mathrm{~h}^{-1}$ depending on the storage temperature $\left(5\right.$ to $\left.25^{\circ} \mathrm{C}\right)$.

Regression analysis was carried out to find a relation between the fruit volume change and both wax solution concentrations and storage temperatures. Equation (5) shows the most appropriate form for the relationship between the fruit volume change and wax solution concentrations at different storage temperatures. Equation (6) shows the most appropriate form for the relationship between the fruit volume change and storage temperatures at different wax solution concentrations. The constants of these equations and coefficient of determination are listed in Table 3.

$$
\begin{aligned}
& \mathrm{VC}=\mathrm{a} \mathrm{WX}^{2}+\mathrm{b} \mathrm{WX}+\mathrm{c} \\
& \mathrm{VC}=\mathrm{a} \mathrm{T} \mathrm{T}^{2}+\mathrm{b} \mathrm{T}+\mathrm{c}
\end{aligned}
$$

Where:-

VC is the cucumber volume change $\left(\mathrm{cm}^{3} \mathrm{~h}^{-1}\right)$

Surface area change: Figures 7 and 8 show the effect of different wax solution concentrations and storage temperatures on change in cucumber fruit surface area. The results indicated that the surface area change decreases with increasing wax solution concentrations but it increases with increasing storage temperature, where, it decreased from 0.419 to $0.111 \mathrm{~cm}^{2} \mathrm{~h}^{-1}$ when the wax solution concentrations increased from 0 (control) to $100 \%$. On the other hand, change of surface area increased from 0.151 to $0.358 \mathrm{~cm}^{2} \mathrm{hr}^{-1}$ with the storage temperatures increased from 5 to $25^{\circ} \mathrm{C}$ (room temperature). The overall average of surface area change decreased from $0.419 \pm 0.135$ to $0.111 \pm 0.037 \mathrm{~cm}^{2}$ $\mathrm{h}^{-1}$ when the wax concentration changed from 0 to $100 \%$. The overall average of surface area change ranged from $0.151 \pm 0.079$ to $0.358 \pm$

\begin{tabular}{|c|c|c|c|c|}
\hline \multicolumn{5}{|c|}{ Cucumber Volume Change } \\
\hline \multirow{2}{*}{ Wax Solution Concentrations (\%) } & \multicolumn{3}{|c|}{ Constants } & \multirow{2}{*}{$\mathbf{R}^{2}$} \\
\hline & $\mathbf{a}$ & b & c & \\
\hline 0 (Control) & 0.0007 & -0.0047 & 0.2546 & 0.992 \\
\hline 25 & 0.0002 & 0.0028 & 0.1715 & 0.999 \\
\hline 50 & 0.0002 & $-6 \times 10^{-5}$ & 0.1403 & 1 \\
\hline 75 & 0.0001 & -0.0003 & 0.1048 & 0.997 \\
\hline 100 & $-9 \times 10^{-6}$ & 0.0029 & 0.0753 & 0.995 \\
\hline \multirow{2}{*}{ Temperature $\left({ }^{\circ} \mathrm{C}\right)$} & \multicolumn{3}{|c|}{ Constants } & $\mathbf{R}^{2}$ \\
\hline & a & b & c & 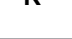 \\
\hline 5 & $9 \times 10^{-6}$ & -0.0024 & 0.2424 & 0.998 \\
\hline 10 & $1 \times 10^{-5}$ & -0.0033 & 0.291 & 0.998 \\
\hline 15 & $1 \times 10^{-5}$ & -0.0034 & 0.3233 & 0.993 \\
\hline 25 (Room Temperature) & $3 \times 10^{-5}$ & -0.0074 & 0.541 & 0.997 \\
\hline
\end{tabular}
$0.174 \mathrm{~cm}^{2} \mathrm{~h}^{-1}$ depending on the storage temperature $\left(5\right.$ to $\left.25^{\circ} \mathrm{C}\right)$.

Table 3: The constants a, b, c and coefficient of determination for volume change at the different wax solution concentrations and the different storage temperatures.

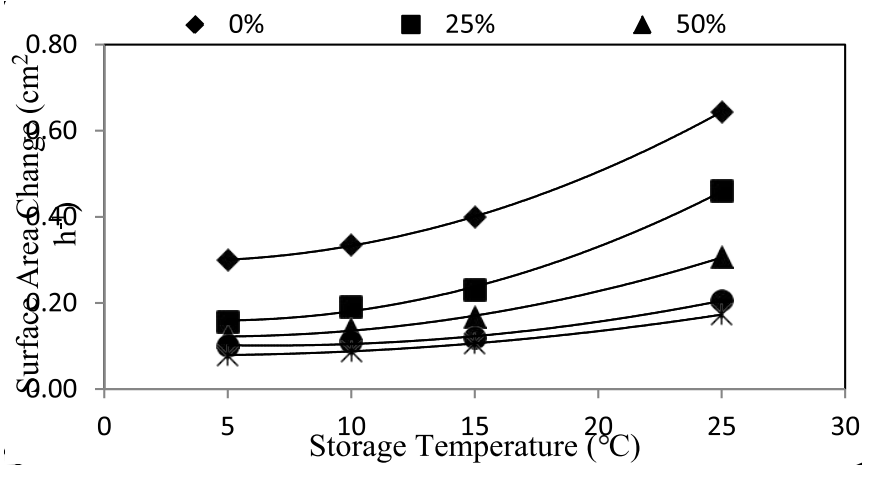

Figure 7: Effect of wax solution concentrations on cucumber fruit surface area change at different storage temperatures.

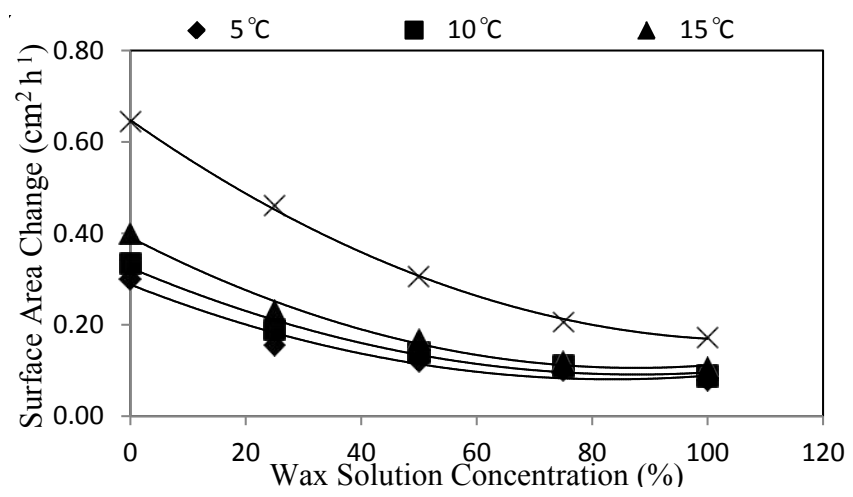

Figure 8: Effect of storage temperature on the cucumber fruit surface area change at different wax solution concentrations. 
Citation: Bahnasawy AH, Khater EG (2014) Effect of Wax Coating on the Quality of Cucumber Fruits during Storage. J Food Process Technol 5: 339. doi:10.4172/2157-7110.1000339

Page 5 of 8

\begin{tabular}{|c|c|c|c|c|}
\hline \multicolumn{5}{|c|}{ Cucumber Surface Area Change } \\
\hline $\begin{array}{c}\text { Wax Solution } \\
\text { Concentrations (\%) }\end{array}$ & $\mathbf{3}$ & \multirow{2}{*}{ Constants } \\
\hline $\mathbf{0}$ (Control) & 0.0007 & -0.0043 & 0.3039 & 1 \\
\hline $\mathbf{2 5}$ & 0.0007 & -0.0065 & 0.1745 & 0.997 \\
\hline $\mathbf{5 0}$ & 0.0004 & -0.0041 & 0.1322 & 0.999 \\
\hline $\mathbf{7 5}$ & 0.0003 & -0.004 & 0.1146 & 0.994 \\
\hline $\mathbf{1 0 0}$ & 0.0002 & -0.0012 & 0.0801 & 0.999 \\
\hline \multirow{3}{|c|}{ Constants } \\
\hline Temperature $\left.\mathbf{(}^{\circ} \mathbf{C}\right)$ & $\mathbf{a}$ & $\mathbf{b}$ & $\mathbf{c}$ & $\mathrm{R}^{2}$ \\
\hline $\mathbf{5}$ & $3 \times 10^{-5}$ & -0.0049 & 0.2879 & 0.959 \\
\hline $\mathbf{1 0}$ & $3 \times 10^{-5}$ & -0.0053 & 0.3245 & 0.980 \\
\hline $\mathbf{1 5}$ & $4 \times 10^{-5}$ & -0.0065 & 0.391 & 0.988 \\
\hline $\mathbf{2 5}$ (Room Temperature) & $4 \times 10^{-5}$ & -0.0089 & 0.6479 & 0.999 \\
\hline
\end{tabular}

Table 4: The constants $a, b, c$ and coefficient of determination for surface area change at the different wax solution concentrations and the different storage temperatures.

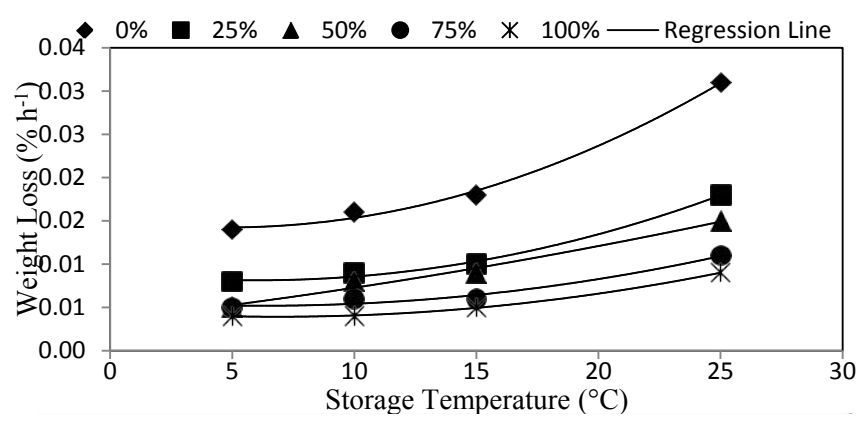

Figure 9: Effect of wax coating on cucumber fruit weight loss at different storage temperatures.

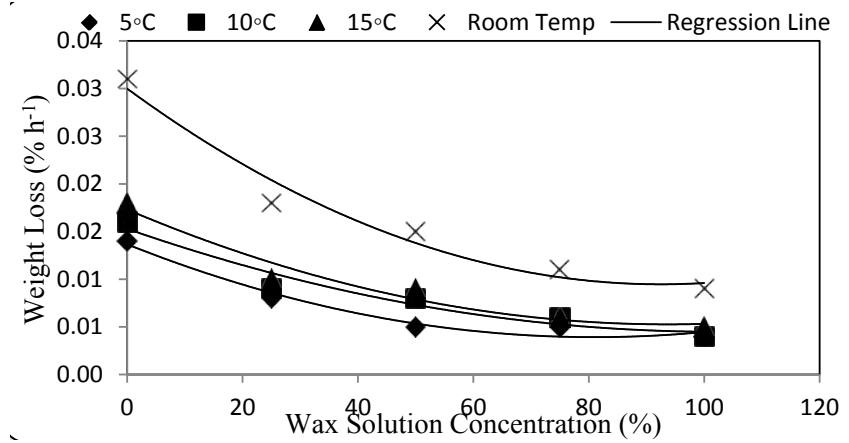

Figure 10: Effect of storage temperatures on cucumber fruit weight loss at dif ferent wax solution concentrations.

Regression analysis was carried out to find a relation between the fruit surface area change and both wax solution concentrations and storage temperatures. Equation (7) shows the most appropriate form for the relationship between the fruit surface area change and wax solution concentrations at different storage temperatures. Equation (8) shows the most appropriate form for the relationship between the fruit surface area change and storage temperatures at different wax solution concentrations. The constants of these equations and coefficient of determination are listed in Table 4.

$$
\mathrm{SAC}=\mathrm{a} \mathrm{WX}^{2}+\mathrm{b} W \mathrm{~W}+\mathrm{c}
$$

$\mathrm{SAC}=\mathrm{a} \mathrm{T}^{2}+\mathrm{b} \mathrm{T}+\mathrm{c}$

Where:-

SAC is the cucumber surface area change $\left(\mathrm{cm}^{2} \mathrm{~h}^{-1}\right)$

Weight Loss: Figures 9 and 10 show the effect of different wax solution concentrations and storage temperatures on change in weight loss of fruit cucumber. The results indicated that the weight loss decreases with increasing wax solution concentrations but it increases with increasing temperature storage, where, it decreased from 0.020 to $0.005 \% \mathrm{~h}^{-1}$ when the wax solution increased from 0 (control) to $100 \%$. On the other hand, weight loss increased from 00073 to $0.017 \% \mathrm{~h}^{-1}$ with the storage temperatures increased from 5 to $25^{\circ} \mathrm{C}$ (room temperature). These results agreed with those obtained by [17]. The overall average of weight loss decreased from $0.020 \pm 0.007$ to $0.005 \pm 0.002 \% \mathrm{~h}^{-1}$ when the wax concentration changed from 0 to $100 \%$. The overall average of weight loss ranged from $0.007 \pm 0.004$ to $0.017 \pm 0.008 \% \mathrm{~h}^{-1}$ depending on the storage temperature $\left(5\right.$ to $\left.25^{\circ} \mathrm{C}\right)$.

Regression analysis was carried out to find a relation between the fruit weight loss and both wax solution concentrations and storage temperatures. Equation (9) shows the most appropriate form for the relationship between the fruit weight loss and wax solution concentrations at different storage temperatures. Equation (10) shows the most appropriate form for the relationship between the fruit weight loss and storage temperatures at different wax solution concentrations. The constants of these equations and coefficient of determination are listed in Table 5.

$$
\begin{aligned}
& \mathrm{WL}=\mathrm{a} \mathrm{WX}^{2}+\mathrm{b} \mathrm{WX}+\mathrm{c} \\
& \mathrm{WL}=\mathrm{a} \mathrm{T}^{2}+\mathrm{b} \mathrm{T}+\mathrm{c}
\end{aligned}
$$

Where:-

$\mathrm{WL}$ is the cucumber weight loss $\left(\% \mathrm{~h}^{-1}\right)$

Effect of wax coating and temperature storage on hardness change rate of cucumber fruits: Figures 11 and 12 show the effect of different wax solution concentrations and storage temperatures on hardness change rate of cucumber fruits. The results indicated that the hardness change rate decreases with increasing wax solution concentrations but it increases with increasing storage temperature, where, it decreased from 1.079 to $0.530 \mathrm{~N} \mathrm{~h}^{-1}$ when the wax solution concentrations increased from 0 (control) to $100 \%$. On the other hand,

\begin{tabular}{|c|c|c|c|c|}
\hline \multicolumn{5}{|c|}{ Cucumber Weight Change } \\
\hline \multirow{2}{*}{$\begin{array}{c}\text { Wax Solution } \\
\text { Concentrations (\%) }\end{array}$} & \multicolumn{3}{|c|}{ Constants } & \multirow{2}{*}{$\mathrm{R}^{2}$} \\
\hline & $\mathbf{a}$ & b & c & \\
\hline 0 (Control) & $4 \times 10^{-5}$ & -0.0003 & 0.0145 & 0.991 \\
\hline 25 & $2 \times 10^{-5}$ & -0.0005 & 0.0098 & 0.998 \\
\hline 50 & $2 \times 10^{-5}$ & 0.0001 & 0.0047 & 0.990 \\
\hline 75 & $2 \times 10^{-5}$ & -0.0002 & 0.0055 & 0.972 \\
\hline 100 & $1 \times 10^{-5}$ & $-5 \times 10^{-5}$ & 0.0038 & 0.995 \\
\hline \multirow{2}{*}{ Temperature ( $\left.{ }^{\circ} \mathrm{C}\right)$} & \multicolumn{3}{|c|}{ Constants } & \multirow{2}{*}{$\mathrm{R}^{2}$} \\
\hline & $\mathbf{a}$ & b & c & \\
\hline 5 & $1 \times 10^{-6}$ & -0.0002 & 0.0134 & 0.988 \\
\hline 10 & $1 \times 10^{-6}$ & -0.0002 & 0.0158 & 0.948 \\
\hline 15 & $2 \times 10^{-6}$ & -0.0003 & 0.0175 & 0.959 \\
\hline 25 (Room Temperature) & $2 \times 10^{-6}$ & -0.0004 & 0.0304 & 0.973 \\
\hline
\end{tabular}
the hardness in cucumber fruits increased from 0.687 to $1.511 \mathrm{~N} \mathrm{~h}^{-1}$ with the storage temperature increased from 5 to $25^{\circ} \mathrm{C}$ [18]. The overall

Table 5: The constants a, b, c and coefficient of determination for weight loss at the different wax solution concentrations and the different storage temperatures. 


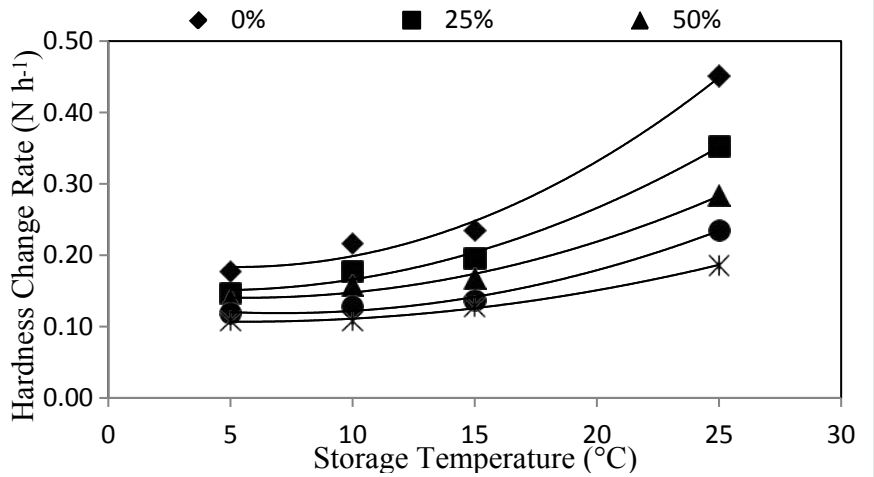

Figure 11: Effect of wax coating on hardness change rate in cucumber fruits at different storage temperatures.

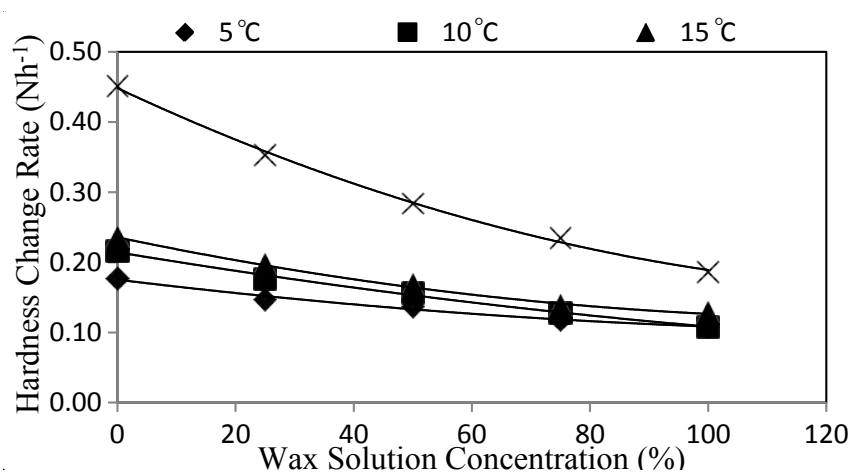

Figure 12: Effect of storage temperature on hardness change rate in cucumber fruits at different wax solution concentrations.

\begin{tabular}{|c|c|c|c|c|}
\hline \multicolumn{5}{|c|}{ Cucumber Hardness Change Rate } \\
\hline \multirow{2}{*}{$\begin{array}{l}\text { Wax Solution Concentrations } \\
(\%)\end{array}$} & \multicolumn{3}{|c|}{ Constants } & \multirow{2}{*}{$\mathrm{R}^{2}$} \\
\hline & a & b & c & \\
\hline Control & 0.0007 & -0.0072 & 0.2024 & 0.989 \\
\hline 25 & 0.0005 & -0.0041 & 0.1599 & 0.992 \\
\hline 50 & 0.0004 & -0.0042 & 0.1523 & 0.989 \\
\hline 75 & 0.0004 & -0.0051 & 0.1364 & 0.993 \\
\hline 100 & 0.0002 & -0.0023 & 0.1131 & 0.996 \\
\hline \multirow{2}{*}{ Temperature $\left({ }^{\circ} \mathrm{C}\right)$} & \multicolumn{3}{|c|}{ Constants } & \multirow{2}{*}{$\mathrm{R}^{2}$} \\
\hline & a & b & c & \\
\hline 5 & $4 \times 10^{-6}$ & -0.0001 & 0.1751 & 0.985 \\
\hline 10 & $3 \times 10^{-6}$ & -0.0014 & 0.2143 & 0.994 \\
\hline 15 & $7 \times 10^{-6}$ & -0.0018 & 0.3356 & 0.996 \\
\hline Room Temperature & $1 \times 10^{-5}$ & -0.0039 & 0.4483 & 0.998 \\
\hline
\end{tabular}

Table 6: The constants a, b, c and coefficient of determination for hardness change at the different wax solution concentrations and the different storage temperatures.

average of hardness change rate decreased from $1.079 \pm 0.107$ to 0.530 $\pm 0.032 \mathrm{~N} \mathrm{~h}^{-1}$ when the wax concentration changed from 0 to $100 \%$. The overall average of hardness change rate ranged from $0.687 \pm 0.024$ to $1.511 \pm 0.093 \mathrm{~N} \mathrm{~h}^{-1}$ depending on the storage temperature $\left(5\right.$ to $\left.25^{\circ} \mathrm{C}\right)$.

Regression analysis was carried out to find a relation between the fruit hardness change and both wax solution concentrations and storage temperatures. Equation (11) shows the most appropriate form for the relationship between the fruit hardness change and wax solution concentrations at different storage temperatures. Equation (12) shows the most appropriate form for the relationship between the fruit hardness change and storage temperatures at different wax solution concentrations. The constants of these equations and coefficient of determination are listed in Table 6.

$$
\begin{aligned}
& \mathrm{H}=\mathrm{a} \mathrm{WX}^{2}+\mathrm{bWX}+\mathrm{c} \\
& \mathrm{H}=\mathrm{a} \mathrm{T}^{2}+\mathrm{b} \mathrm{T}+\mathrm{c}
\end{aligned}
$$

Where:-

$\mathrm{H}$ is the hardness change $\left(\% \mathrm{~h}^{-1}\right)$

Effect of wax coating and storage temperature on total soluble solids (TSS) in cucumber fruits: Figures 13 and 14 show the effect of different wax solution concentrations and storage temperatures on TSS change in cucumber fruits. The results indicated that the TSS decreases with increasing wax concentrations but it increases with increasing temperature storage, where, it decreased from 0.008 to $0.003 \% \mathrm{~h}^{-1}$ when the wax solution concentrations increased from 0 (control) to $100 \%$. On the other hand, TSS change increased from 0.005 to $0.007 \% \mathrm{~h}^{-1}$ with the storage temperatures increased from 5 to $25^{\circ} \mathrm{C}$ (room temperature). These results agreed with those obtained by [17]. The overall average of TSS change decreased from $0.008 \pm 0.0016$ to $0.003 \pm 0.0004 \% \mathrm{~h}^{-1}$ when the wax concentration changed from 0 to $100 \%$. The overall average of TSS change ranged from $0.005 \pm 0.001$ to $0.007 \pm 0.002 \% \mathrm{~h}^{-1}$ depending on the storage temperature $\left(5\right.$ to $25^{\circ} \mathrm{C}$ ).

Regression analysis was carried out to find a relation between the

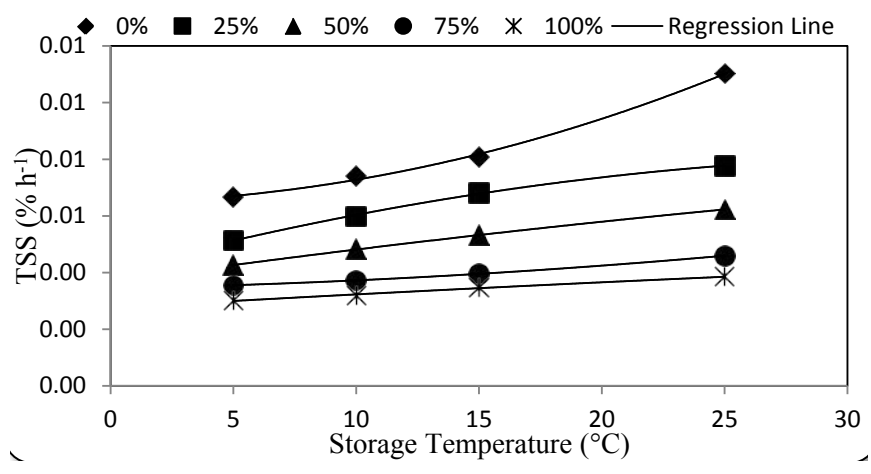

Figure 13: Effect of wax solution on TSS change at different storage temperatures.

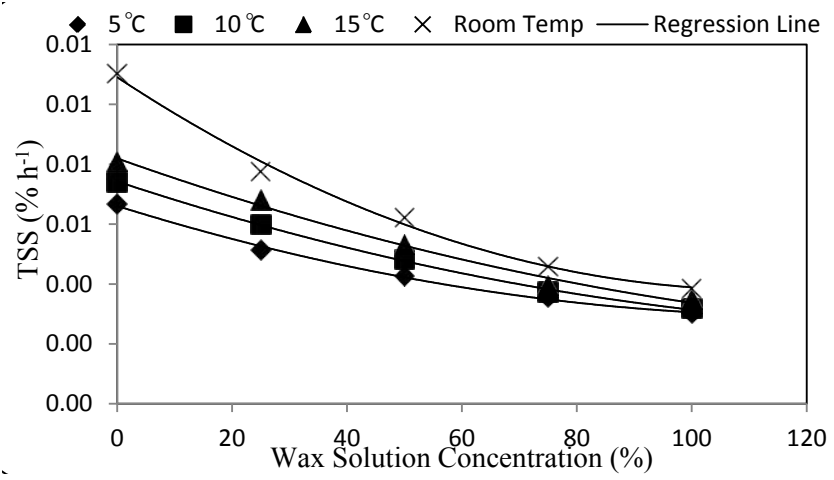

Figure 14: Effect of storage temperature on TSS change at different wax solution concentrations. 
Citation: Bahnasawy AH, Khater EG (2014) Effect of Wax Coating on the Quality of Cucumber Fruits during Storage. J Food Process Technol 5: 339. doi:10.4172/2157-7110.1000339

Page 7 of 8

\begin{tabular}{|c|c|c|c|c|}
\hline \multicolumn{5}{|c|}{ Cucumber TSS change } \\
\hline \multirow{2}{*}{$\begin{array}{c}\text { Wax Solution Concentrations } \\
(\%)\end{array}$} & \multicolumn{3}{|c|}{ Constants } & \multirow{2}{*}{$\mathrm{R}^{2}$} \\
\hline & $\mathbf{a}$ & b & c & \\
\hline Control & $7 \times 10^{-6}$ & $1 \times 10^{-5}$ & 0.0065 & 0.997 \\
\hline 25 & $-3 \times 10^{-6}$ & 0.0002 & 0.0041 & 0.999 \\
\hline 50 & $-8 \times 10^{-7}$ & 0.0001 & 0.0037 & 1 \\
\hline 75 & $1 \times 10^{-6}$ & $2 \times 10^{-5}$ & 0.0034 & 0.999 \\
\hline 100 & $-2 \times 10^{-7}$ & $5 \times 10^{-5}$ & 0.0118 & 0.988 \\
\hline \multirow{2}{*}{ Temperature ( $\left.{ }^{\circ} \mathrm{C}\right)$} & \multicolumn{3}{|c|}{ Constants } & \multirow{2}{*}{$\mathrm{R}^{2}$} \\
\hline & a & b & c & \\
\hline 5 & $2 \times 10^{-7}$ & $6 \times 10^{-5}$ & 0.0066 & 0.997 \\
\hline 10 & $2 \times 10^{-7}$ & $-6 \times 10^{-5}$ & 0.0074 & 0.999 \\
\hline 15 & $2 \times 10^{-7}$ & $-7 \times 10^{-5}$ & 0.0082 & 0.991 \\
\hline Room Temperature & $6 \times 10^{-7}$ & 0.0001 & 0.0109 & 0.995 \\
\hline
\end{tabular}

Table 7: The constants $a, b, c$ and coefficient of determination for TSS change at the different wax solution concentrations and the different storage temperatures.

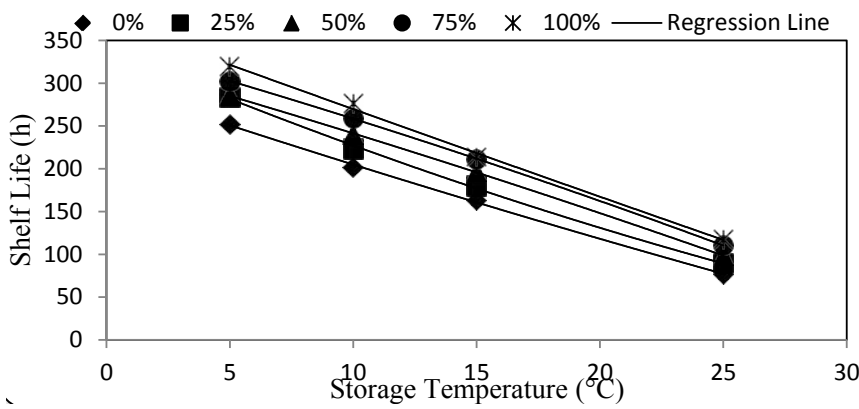

Figure 15: Effect of wax coating on the shelf life of the cucumber at different storage temperatures.

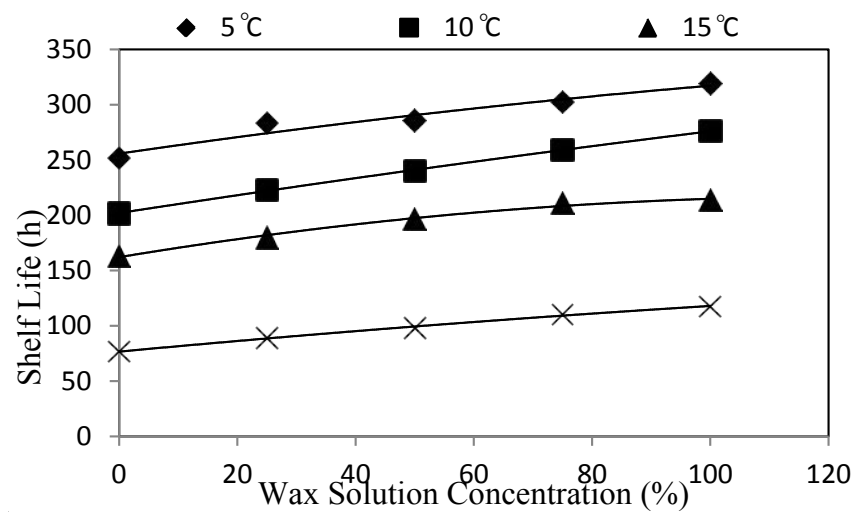

Figure 16: Effect of storage temperature on the shelf life of the cucumber at different wax solution concentrations.

fruit TSS change and both wax solution concentrations and storage temperatures. Equation (13) shows the most appropriate form for the relationship between the fruit TSS change and wax solution concentrations at different storage temperatures. Equation (14) shows the most appropriate form for the relationship between the fruit TSS change and storage temperatures at different wax solution concentrations. The constants of these equations and coefficient of determination are listed in Table 7.

$\mathrm{TSS}=\mathrm{a} \mathrm{WX}^{2}+\mathrm{b} \mathrm{WX}+\mathrm{c}$
$\mathrm{TSS}=\mathrm{a} \mathrm{T}^{2}+\mathrm{b} \mathrm{T}+\mathrm{c}$

Where:-

TSS is the cucumber TSS change $\left(\% \mathrm{~h}^{-1}\right)$

Effect of storage temperature on the shelf life of the cucumber coated with different wax solution percentage: Figures 15 and 16 show the effect of storage temperature on the shelf life of the cucumber coated with different wax solution percentage. The results indicated that the shelf life increases with increasing wax solution concentrations meanwhile, it increases with increasing temperature storage, where, it increased from 173.4 to $231.6 \mathrm{~h}$ when the wax solution concentration increased from 0 (control) to $100 \%$. On the other hand, the shelf life in cucumber fruits increased from 98.40 to $288.48 \mathrm{~h}$ when the storage temperature increased from 5 to $25^{\circ} \mathrm{C}$ (room temperature). These results were in agreement with those obtained by [16]. The overall average of shelf life decreased from $288.48 \pm 22.38$ to $231.60 \pm 75.77$ $\mathrm{h}$ when the wax concentration changed from 0 to $100 \%$. The overall average of shelf life change ranged from $288.48 \pm 22.38$ to $98.40 \pm 14.64$ $\mathrm{h}$ depending on the storage temperature 5 to $25^{\circ} \mathrm{C}$.

Regression analysis was carried out to find a relation between the fruit shelf life and both wax solution concentrations and storage temperatures. Equation (15) shows the most appropriate form for the relationship between the fruit shelf life and wax solution concentrations at different storage temperatures. Equation (16) shows the most appropriate form for the relationship between the fruit shelf life and storage temperatures at different wax solution concentrations. The constants of these equations and coefficient of determination are listed in Table 8.

$$
\begin{aligned}
& \mathrm{SL}=\mathrm{a} \mathrm{WX}^{2}+\mathrm{bWX}+\mathrm{c} \\
& \mathrm{SL}=\mathrm{a} \mathrm{T}^{2}+\mathrm{b} \mathrm{T}+\mathrm{c}
\end{aligned}
$$

Where:-

$\mathrm{SL}$ is the cucumber shelf life (h)

\section{Summary and Conclusions}

The experiment was carried out to study the effect of wax coating (control, 25, 50, 75 and 100\%) and storage temperatures (room temperature, 15,10 and $5^{\circ} \mathrm{C}$ ) on cucumber fruits quality, (diameter change, length change, volume change, area change, weight loss, hardness change rate and TSS change on cucumber fruits). Shelf life of the cucumber was also studied. The obtained results can be summarized

\begin{tabular}{|c|c|c|c|c|}
\hline \multicolumn{5}{|c|}{ Cucumber Shelf life } \\
\hline \multirow{2}{*}{$\begin{array}{c}\text { Wax Solution Concentrations } \\
(\%)\end{array}$} & \multicolumn{3}{|c|}{ Constants } & \multirow{2}{*}{$\mathrm{R}^{2}$} \\
\hline & a & b & c & \\
\hline 0 (Control) & 0.0327 & -9.6589 & 298.23 & 0.999 \\
\hline 25 & 0.0851 & -12.172 & 340.43 & 0.997 \\
\hline 50 & -0.0393 & -8.1469 & 326.79 & 0.993 \\
\hline 75 & -0.0524 & -8.0465 & 344.2 & 0.996 \\
\hline 100 & 0.0087 & -10.499 & 373.83 & 0.988 \\
\hline \multirow{2}{*}{ Temperature $\left({ }^{\circ} \mathrm{C}\right)$} & \multicolumn{3}{|c|}{ Constants } & \multirow{2}{*}{$\mathrm{R}^{2}$} \\
\hline & $\mathbf{a}$ & b & c & \\
\hline 5 & 0.0016 & 0.779 & 255.7 & 0.997 \\
\hline 10 & -0.0008 & 0.8215 & 202.01 & 0.999 \\
\hline 15 & -0.0036 & 0.8846 & 162.1 & 0.991 \\
\hline 25 (Room Temperature) & -0.0008 & 0.4951 & 76.731 & 0.995 \\
\hline
\end{tabular}
as follows:

Table 8: The constants $a, b, c$ and coefficient of determination for shelf life at the different wax solution concentrations and the different storage temperatures. 
- The diameter change decreased from 0.053 to $0.017 \mathrm{~mm} \mathrm{~h}^{-1}$ when the wax solution increased from 0 to $100 \%$. On the other hand, loss of diameter increased from 0.021 to $0.049 \mathrm{~mm} \mathrm{~h}^{-1}$ with the storage temperature increased from 5 to $25^{\circ} \mathrm{C}$.

- The length change decreased from 0.199 to $0.0054 \mathrm{~mm} \mathrm{~h}^{-1}$ when the wax solution concentrations increased from 0 to $100 \%$. On the other hand, the length change increased from 0.074 to 0.168 $\mathrm{mm} \mathrm{h}^{-1}$ with the storage temperature changed from 5 to $25^{\circ} \mathrm{C}$.

- The volume change decreased from 0.349 to $0.113 \mathrm{~cm}^{3} \mathrm{~h}^{-1}$ when the wax solution increased from 0 to $100 \%$. On the other hand, loss of volume cucumber fruit increased from 0.154 to 0.300 $\mathrm{cm}^{3} \mathrm{~h}^{-1}$ with the storage temperatures increased from 5 to $25^{\circ} \mathrm{C}$.

- The surface area change decreased from 0.419 to $0.111 \mathrm{~cm}^{2}$ $\mathrm{h}^{-1}$ when the wax solution concentrations increased from 0 to $100 \%$. On the other hand, change of surface area increased from 0.151 to $0.358 \mathrm{~cm}^{2} \mathrm{~h}^{-1}$ with the storage temperatures increased from 5 to $25^{\circ} \mathrm{C}$.

- The weight loss decreased from 0.020 to $0.005 \% \mathrm{~h}^{-1}$ when the wax solution increased from 0 to $100 \%$. On the other hand, weight loss increased from 00073 to $0.017 \% \mathrm{~h}^{-1}$ with the storage temperatures increased from 5 to $25^{\circ} \mathrm{C}$.

- The hardness change rate decreased from 1.079 to $0.530 \mathrm{~N}$ $\mathrm{h}^{-1}$ when the wax solution concentrations increased from 0 to $100 \%$. On the other hand, the hardness in cucumber fruits increased from 0.687 to $1.511 \mathrm{~N} \mathrm{~h}^{-1}$ with the storage temperature increased from 5 to $25^{\circ} \mathrm{C}$.

- The TSS decreased from 0.008 to $0.003 \% \mathrm{~h}^{-1}$ when the wax solution concentrations increased from 0 to $100 \%$. On the other hand, TSS change increased from 0.005 to $0.007 \% \mathrm{~h}^{-1}$ with the storage temperatures increased from 5 to $25^{\circ} \mathrm{C}$.

The shelf life increases with increasing wax solution but it increases with increasing storage temperature. It increased from 173.4 to 231.6 $\mathrm{h}$ when the wax solution concentration increased from 0 to $100 \%$. On the other hand, the shelf life in cucumber fruits increased from 98.40 to $288.48 \mathrm{~h}$ with the storage temperature increased from 5 to $25^{\circ} \mathrm{C}$.

\section{References}

1. Lucier G, Jerardo A (2007) Vegetables and Melons Outlook/VGS-319. Economic Research Service, USDA.

2. CAPMS (2011) Annual year book for general statistics. Egypt: Central Agency for Public Mobilization and Statistics of ARE.
3. Thirupathi V, Sasikala S, Kennedy ZJ (2006) Preservation of fruits and vegetables by wax coating. Science Tech Enterpreneur.

4. Amarante C, Banks NH, Ganesh S (2001a) Effects of coating concentration ripening stage, water status and fruit temperature on pear susceptibility to friction discolouration. Postharvest Biol Technol 21: 283- 290.

5. Amarante C, Banks NH, Ganesh S (2001b) Relationship between characte of skin cover of coated pears and permeance to water vapour and gases. Postharvest Biol Technol 21: 291-301.

6. Fukushima T, Yamazaki M, Tsugiyama T (1977) Chilling-injury in cucumber fruits. I. Effects of storage temperature on symptoms and physiological changes. Sci Hortic 6: 185-197.

7. Marcellin P, Ulrich R (1983) Comportament des fruits et légumes en conditions modulées et programmées. Int. J. Refrigeration 6: 329-336.

8. Wang CY, (1989) Chilling injury of fruits and vegetables. Food Rev Int 5: 209236

9. Musmade AM, Desai UT (1998) Cucumber and melon. Handbook of Vegetable Science and Technology. Marcel Dekker Inc., New York.

10. Tatsumi Y, Maeda K, Murata T (1987) Morphological changes in cucumber fruit surfaces associated with chilling injury. J Japan Soc Hort Sci 56: 187-192.

11. Tatsumi Y, Isogai M, Sei S, Srilaong V (2006) Changes in ascorbic acid content and ascorbate metabolism-related enzyme activities during storage in cucumber (Cucumis sativus L.) and balsam pear (Momordica charantia L.). Acta Hortic 712:755-761.

12. FernándezTrujillo JP, Martínez JA (2006) Ultrastructure of the onset of chilling injury in cucumber fruit. J. Appl Bot Food Qual 80: 100-110.

13. Martínez JA, Fernández-Trujillo JP (2007) Necrotrophic fungi associated with epidermal microcracking caused by chilling injury in pickling cucumber fruit. Pesq Agropec Bras 42: 593-598.

14. Pérez-Díaz IM, McFeeters RF (2008) Microbiological preservation of cucumbers for bulk storage using acetic acid and food preservatives. J Food Sci 73: M287-M291.

15. Apeland $\mathrm{J}$ (1966) Factors affecting non-parasitic disorders of the harvested product of cucumber. Acta Hort 4: 102-104.

16. Ryall AL, Lipton WJ (1979) Handling, transportation and storage of fruits and vegetables. Second edition, AVI Publishing Company, INC. Westport, Connecticut.

17. Yonemoto $\mathrm{Y}$, Higuchi $\mathrm{H}$, Kitano $\mathrm{Y}$ (2002) Effect of storage temperature and wax coating on ethylene production, respiration and shelf-life in cherimoya fruit. $J$ Japan Soc Hort Sci 71: 643- 640.

18. Karakas B, Yildiz F (2007) Peroxidation of membrane lipids in minimally processed cucumbers packaged under modified atmospheres. Food Chemistry 100: 1011-1018 